\title{
DEVELOPMENT OF CONTINUOUS SYSTEM BASED ON NANOSCALE ZERO VALENT IRON PARTICLES FOR PHOSPHORUS REMOVAL
}

\author{
Seiya TAKAMI ${ }^{1}$, Osama ELJAMAL ${ }^{2}$, Ahmed M. E. KHALIL ${ }^{3}$, Ramadan ELJAMAL 4 \\ and Nobuhiro MATSUNAGA ${ }^{5}$ \\ ${ }^{1}$ Student Member of JSCE, IGSES, Dept. of Earth System Science and Technology, Kyushu University \\ (6-1 Kasuga-Koen, Kasuga-shi, Fukuoka 816-8580, Japan) \\ E-mail: takami@esst.kyushu-u.ac.jp \\ ${ }^{2}$ Assoc. Prof., IGSES, Dept. of Earth System Science and Technology, Kyushu University \\ (6-1 Kasuga-Koen, Kasuga-shi, Fukuoka 816-8580, Japan) \\ E-mail: osama-eljamal@kyudai.jp \\ ${ }^{3}$ Faculty of Engineering, Dept. of Chemical Engineering, Cairo University (Giza, 12613, Egypt) \\ IGSES, Dept. of Earth System Science and Technology, Kyushu University \\ (6-1 Kasuga-Koen, Kasuga-shi, Fukuoka 816-8580, Japan) \\ E-mail: ahmad.alsayed@eng1.cu.edu.eg \\ ${ }^{4}$ IGSES, Dept. of Earth System Science and Technology, Kyushu University \\ (6-1 Kasuga-Koen, Kasuga-shi, Fukuoka 816-8580, Japan) \\ E-mail: ramadaneljamal54@gmail.com \\ ${ }^{5}$ Fellow Member of JSCE, Prof., IGSES, Dept. of Earth System Science and Technology, Kyushu University \\ (6-1 Kasuga-Koen, Kasuga-shi, Fukuoka 816-8580, Japan) \\ E-mail: matunaga@esst.kyushu-u.ac.jp
}

\begin{abstract}
Nanoscale Zero Valent Iron (NZVI) is one of the materials that have gained attention in the field of water treatment and environmental remediation in recent years. The main purpose of this study is to develop and evaluate a phosphorus removal system using NZVI particles. The NZVI used for the experiments was synthesized under optimum conditions using the chemical reduction method. This continuous system consisted of Continuous Stirred Flask Reactor (CSFR), settler, polishing unit, and sand column. The continuous experiment showed that $73.84 \%$ phosphorus was removed mainly at CSFR. Further, $80.62 \%$ total iron was removed and recycled at the settler. Based on the continuous operation results, there was a strong relationship between iron concentration and ORP value $\left(\mathrm{R}^{2}=0.9969\right)$. This result indicated that ORP would be an important monitoring parameter while operating the continuous system. The aerobic condition contributed the highest phosphorus overall removal efficiency (91.37\%) due to the enhancement of iron corrosion. Copper bimetal particles also achieved the highest removal efficiency (94.96\%) after increasing the active site and decreasing the solution $\mathrm{pH}$. Finally, comparing the aerobic and bimetallic cases, we concluded that the bimetallic case is the best condition for removing phosphorus because it could treat large solution volume than the aerobic one could.
\end{abstract}

Key Words : phosphorus removal, nano-scale zero valent iron (NZVI), continuous system

\section{INTRODUCTION}

Phosphorus $(\mathrm{P})$ can be found in the aquatic system in both particulate and dissolved forms. The normal forms of phosphorus in the aqueous system are orthophosphates, polyphosphates, and organic phosphates ${ }^{1)}$.

Phosphorus, which is a non-renewable, non-interchangeable finite resource, is an important nutrient for living organisms (animals, microbes, plants, and algae $)^{2}$. However, the excessive amount of phosphorus present in natural waters is known to cause eutrophication ${ }^{3)} \mathrm{Xu}$ et al. reported that the eutrophication threshold of total phosphorus (T-P) for freshwaters was from 0.02 to $0.10 \mathrm{mg} / \mathrm{L}^{4)}$. Eutrophication results in the depletion of oxygen that leads to death of aquatic animals and adverse effects on the aquatic environment. Phosphorus is found in municipal wastewater, industrial wastewater, agricultural drainage (fertilizer), and household wastewater. Therefore, higher concentration of phosphorus wastewater should be treated before be- 
ing discharged into the aquatic environment. To remove excessive phosphorus from water, chemical precipitation and enhanced bacteria activity were commonly used $^{5}$.

In chemical precipitation, these chemicals, such as $\mathrm{Ca}^{2+6)}, \mathrm{Al}^{3+}{ }^{7)},{ }^{8)}, \mathrm{Mg}^{2+9)}$, and $\mathrm{Fe}^{3+10)}$ were widely used. This is one of the effective methods for removing phosphorus and is suitable where there is low concentration of phosphorus in water. However, if there is high concentration of phosphorus in the water, the system is not suitable because it will require a large amount of chemicals ${ }^{11)}$. Phosphorus removal by using phosphate-accumulating bacteria is also widely used in the wastewater treatment process, but phosphorus removal is limited by bacteria and wastewater conditions. Furthermore, this approach produces excess sludge containing high concentrations of phosphorus and pollutants, such as heavy metals, which are very difficult and costly to treat $\left.{ }^{11)}, 12\right), 13$. Both methods are widely used these days; however, both of them have disadvantages.

In recent years, due to the importance of nanotechnologies, Nanoscale Zero Valent Iron (NZVI) has been investigated and used in the removal of not only phosphorus but also several environmental pollutants such as heavy metals ${ }^{14), 15), 16)}$, nitrate ${ }^{17), 18)}$, and azo dye ${ }^{19)}$ from aqueous systems. Due to their morphological shape, NZVI particles have a large specific surface area that provides more active sites for pollutant removal ${ }^{20)}$. Meanwhile, the activity of reaction with phosphorus could be improved since phosphorus easily reacts with iron ${ }^{21)}$. Results of phosphorus removal using NZVI experiments have been reported. Almeelbi and Bezbaruah ${ }^{22)}$ reported that maximum phosphorus adsorption capacity of NZVI was $24.38 \mathrm{mg} \mathrm{P} / \mathrm{g}$. Eljamal et al. ${ }^{23)}$ reported that the maximum adsorption capacity by $\mathrm{NZVI} / \mathrm{CuCl}_{2}$ had doubled up to $50 \mathrm{mg} \mathrm{P} / \mathrm{g}$. It has been reported also that the phosphorus removal efficiency under oxic condition was higher than under anoxic and anaerobic conditions ${ }^{24)}$.

The mechanism of phosphorus removal by NZVI has not yet been perfectly determined. A few researchers said that the main mechanism of phosphorus with NZVI mainly exhibited adsorption and coprecipitation reaction ${ }^{11}$. However, these reports were mainly focused on the maximum adsorption capacity and its mechanisms by batch experiments. Recently, some reports have focused on the continuous treatment system using NZVI ${ }^{25), 26)}$. No reports specifically shed light on removing phosphorus by adopting a continuous treatment system using NZVI. The objective of this work is to obtain some optimized conditions for removing phosphorus by NZVI using the continuous system. A total of five different experiments were conducted. Three of them were conducted for different gaseous phase conditions by using ambient, aerobic, and anaerobic conditions. Two of them were conducted to investigate the $\mathrm{CuCl}_{2}$ effect for removing.

\section{MATERIALS AND METHODS}

\section{(1) Chemicals}

The following chemical reagents and materials were used: Sodium borohydride $\left(\mathrm{NaBH}_{4}, 98.0 \%\right.$, Junsei Chemical Co., Japan), ferric chloride hexahydrate $\left(\mathrm{FeCl}_{3} \cdot 6 \mathrm{H}_{2} \mathrm{O}, 99.0 \%\right.$, Junsei Chemical Co., Japan), potassium dihydrogen phosphate $\left(\mathrm{KH}_{2} \mathrm{PO}_{4}, 99.5 \%\right.$, Kanto Chemical Co., Japan), and anhydrous copper chloride $\left(\mathrm{CuCl}_{2}, 99.9 \%\right.$, Aldrich Inc., USA). Nitrogen gas purging was done on all prepared solutions for de-oxygenation. All chemicals were applied as delivered without further purification.

\section{(2) Synthesis of NZVI}

NZVI was synthesized following this chemical reaction (Equation (1) $)^{27)}$ :

$$
\begin{aligned}
& 2 \mathrm{FeCl}_{3}+6 \mathrm{NaBH}_{4}+18 \mathrm{H}_{2} \mathrm{O} \rightarrow \\
& 2 \mathrm{Fe}^{0}+21 \mathrm{H}_{2}+6 \mathrm{~B}(\mathrm{OH})_{3}+6 \mathrm{NaCl}
\end{aligned}
$$

Precursor 1 was prepared by dissolving $21.0 \mathrm{~g}$ of $\mathrm{NaBH}_{4}$ in 1,200 mL of deoxygenated deionized water (DIW). Precursor 2 was prepared by dissolving $50.0 \mathrm{~g}$ of $\mathrm{FeCl}_{3} \cdot 6 \mathrm{H}_{2} \mathrm{O}$ in $1,200 \mathrm{~mL}$ of DIW in a separate flask. Then precursor 1 was added to precursor 2 using a peristaltic pump at the rate of $16 \mathrm{~mL} / \mathrm{min}$. with vigorous stirring at $250 \mathrm{rpm}$ under nitrogen condition at constant temperature of $25 \pm 0.5{ }^{\circ} \mathrm{C}$ using a water bath. The synthesis was conducted in 5 $\mathrm{L}$ four-neck glass flask and left $20 \mathrm{~min}$. for aging to complete the reaction ${ }^{23}$. In the case of $\mathrm{CuCl}_{2}$ bimetallic synthesis, $1.0 \mathrm{~g} \mathrm{CuCl}_{2}$ was added to precursor 2 before mixing with precursor $1^{28)}$. The synthesized particles were filtered by vacuum filter, washed with DIW three times, and immediately used in the continuous experiments.

\section{(3) Phosphorus solution quality}

The $\mathrm{KH}_{2} \mathrm{PO}_{4}$ was used as a phosphorus source and it was diluted with tap water by up to $25.6 \pm 1.2 \mathrm{mg}$ $\mathrm{P} / \mathrm{L}$. The phosphorus concentration was fixed in all experiments. Their $\mathrm{pH}, \mathrm{ORP}$, and DO were $7.0 \pm 0.2$, $0.2 \pm 3.5 \mathrm{mV}$, and $10.2 \pm 2.5 \mathrm{mg} \mathrm{DO} / \mathrm{L}$, respectively.

\section{(4) Details of the continuous system}

The flow diagram of the laboratory-scale continuous system is illustrated in Fig. 1. The treatment system consisted of a four-neck flask reactor 


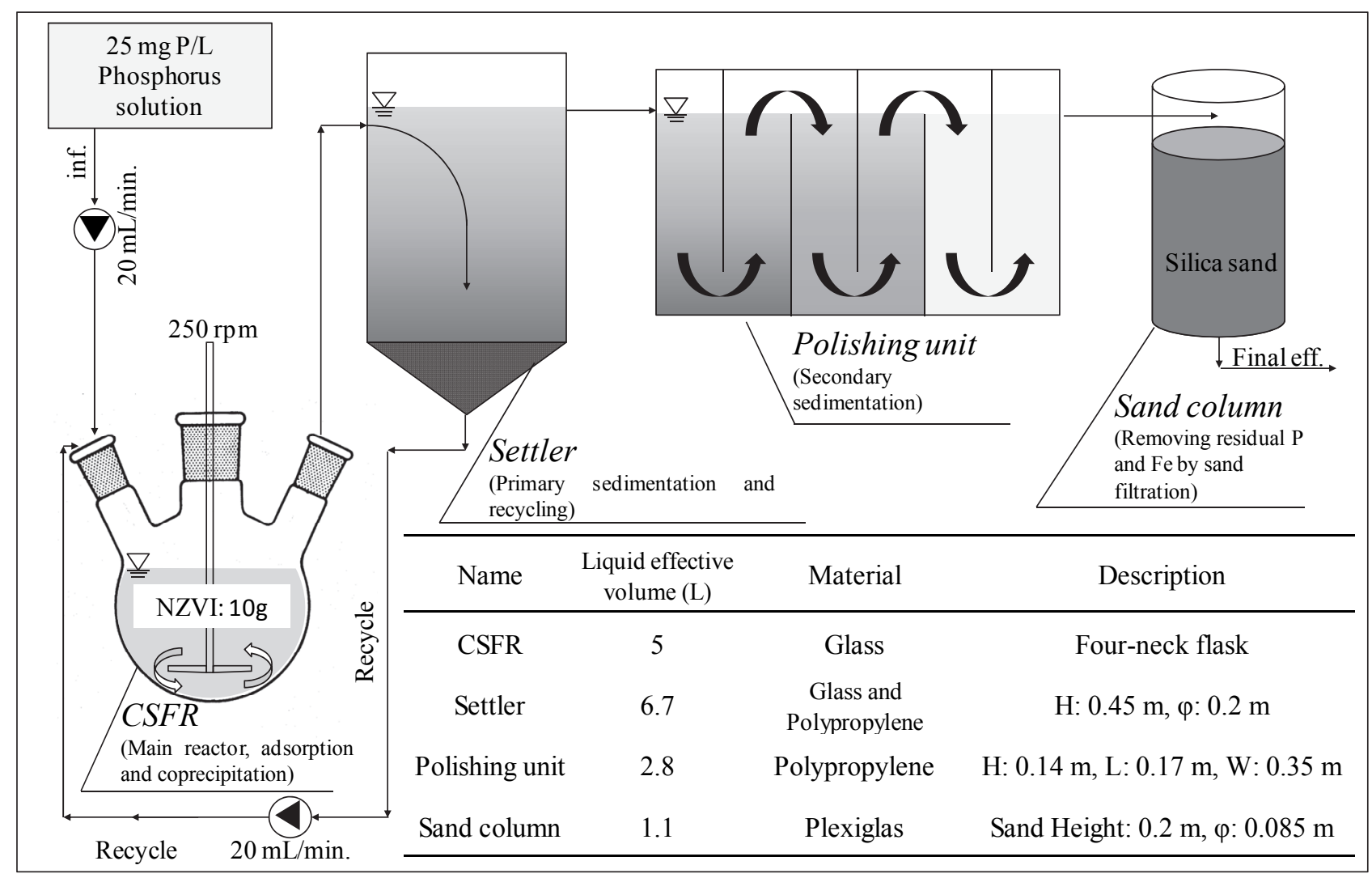

Fig.1 The flow diagram of laboratory-scale continuous system.

Table 1 The operation conditions.

\begin{tabular}{|c|c|c|c|c|c|c|}
\hline $\begin{array}{l}\text { Exp. } \\
\text { No. }\end{array}$ & $\begin{array}{c}\text { NZVI dosage } \\
\text { (g) }\end{array}$ & $\begin{array}{c}\mathrm{CuCl}_{2} \\
\text { bimetal or addition }\end{array}$ & $\begin{array}{l}\text { Gaseous phase } \\
\text { conditions }\end{array}$ & $\begin{array}{l}\text { Air flow rate } \\
\text { (mL/min.) }\end{array}$ & $\begin{array}{l}\text { Solution feeding rate } \\
\qquad(\mathrm{mL} / \mathrm{min} .)\end{array}$ & $\begin{array}{l}\text { Actual initial phosphorus } \\
\text { conc. } \\
(\mathrm{mg} / \mathrm{L})\end{array}$ \\
\hline 1 & 10 & - & Ambient & - & 20 & 23.5 \\
\hline 2 & 10 & - & Aerobic & 1,000 (air) & 20 & 26.1 \\
\hline 3 & 10 & - & Anaerobic & $1,000\left(\mathrm{~N}_{2}\right)$ & 20 & 26.1 \\
\hline 4 & 10 & $\begin{array}{c}\text { Bimetal } \\
\left(1 \mathrm{~g} \mathrm{CuCl}_{2}: 10 \mathrm{~g} \mathrm{NZVI}\right)\end{array}$ & Ambient & - & 20 & 26.1 \\
\hline 5 & 10 & $\begin{array}{c}\text { Addition } \\
\left(1 \mathrm{~g} \mathrm{CuCl}_{2}: 10 \mathrm{~g} \mathrm{NZVI}\right)\end{array}$ & Ambient & - & 20 & 26.1 \\
\hline
\end{tabular}

(CSFR), settler, polishing unit, and sand column. The four-neck flask was a glass flask with an effective volume of $5 \mathrm{~L}$. This unit was installed as the main reactor for removing phosphorus. The phosphorus solution was supplied by a peristaltic pump at 20 $\mathrm{mL} / \mathrm{min}$. and stirred with an impeller (stirrer) at a speed of $250 \mathrm{rpm}$ to mix the phosphorus solution and NZVI vigorously. The pumped solution and NZVI were first reacted here. Especially only CSFR, the temperature was maintained at $25^{\circ} \mathrm{C}$ during the water bath. Other reactor temperatures depended on the room temperature. The settler corresponded to the primary settler. Outflowed NZVI from CSFR were settled by gravitation here. The settler was made by glass with an effective volume of $6.7 \mathrm{~L}$. The settled NZVI was recycled to CSFR by a peristaltic pump at $20 \mathrm{~mL} / \mathrm{min}$. There were two reasons for installing the recycle system. The first reason was to prevent the outflow of NZVI from the whole system. Without this unit, the large quantity of iron compounds might outflow. The second reason was to maintain the stability of iron concentration inside the CSFR. Unreacted NZVI can be used in the CSFR and remove phosphorus again.

The polishing unit was installed as a secondary settler to remove the remaining iron compounds. It was made by polypropylene materials with an effective volume of $2.8 \mathrm{~L}$. Five baffles were installed 
inside the reactor.

The sand column was installed as a final unit to remove the remaining phosphorus and iron compounds by adsorbing them onto the sand surface. The sand can adsorb dissolved phosphorus and iron compounds ${ }^{29}$. The sand column body was made by plexiglas with an effective volume of $1.1 \mathrm{~L}$. The silica sand (JIS standard sand, Silica sand No.5) was packed with $1.1 \mathrm{~L}$.

Five different condition experiments were conducted in this study (Table 1). In all experiments, NZVI dosage and phosphorus concentration were fixed at $10 \mathrm{~g}^{33)}$ and $25.6 \pm 1.2 \mathrm{mg} / \mathrm{L}^{29)}$. To obtain enough contact time inside the CSFR and evaluate the effect of several parameters, the longer hydraulic retention time (HRT) was set at four hours. First, in order to investigate the effect of oxygen on phosphorus removal, three of the experiments were conducted under different gaseous phase conditions using ambient, aerobic, and anaerobic conditions. In experiment 1, the gaseous phase condition in the CSFR was kept at ambient condition, and no air injection was conducted. In experiment 2 , the gaseous phase condition in the CSFR was kept at aerobic condition. In order to obtain the desired condition inside the CSFR, air was injected during the whole duration of the experiment. An air pump (NISSO CHIKARA@4,000 SW, NISSO Co. Ltd. Japan)was used to inject air. The air flow rate was 1,000 $\mathrm{mL} / \mathrm{min}$. In experiment 3 , the gaseous phase condition in the CSFR was kept at anaerobic condition by injecting nitrogen gas during the whole duration of the experiment. The nitrogen flow rate was 1,000 $\mathrm{mL} / \mathrm{min}$. For experiments 4 and 5 , which were conducted under ambient conditions, the effect of $\mathrm{CuCl}_{2}$ on phosphorus removal was investigated. In the NZVI study field, several heavy metals were reported to have enhanced the reactivity because they provided more active site on the surface of NZVI or they served as reductants ${ }^{28), 30}$. The $\mathrm{NZVI} / \mathrm{CuCl}_{2}$ $(10.0 \mathrm{~g}: 1.0 \mathrm{~g})$ bimetallic nano particles ${ }^{28)}$ were used as adsorbents for experiment 4 . In experiment 5, 1.0 $\mathrm{g} \mathrm{CuCl}_{2}$ was added to CSFR before beginning the operation $^{23)}$.

The main difference between experiments 4 and 5 was the manner in which $\mathrm{CuCl}_{2}$ contributed to removing phosphorus. With respect to the bimetallic case, pure $\mathrm{Cu}$ attached on the surface of NZVI and gave more active site. According to previous reports, $\mathrm{NZVI} / \mathrm{CuCl}_{2}$ nanoparticle surface area was 35.1 $\mathrm{m}^{2} / \mathrm{g}$. This value was larger than that of pure NZVI $\left(32.6 \mathrm{~m}^{2} / \mathrm{g}\right)^{31)}$. And with respect to the $\mathrm{CuCl}_{2}$ addition case, $\mathrm{CuCl}_{2}$ reaction with NZVI increased iron corrosion on the surface and provided its surface with copper and copper ferrite particles. These copper compounds enhance electric conductivity (EC) of the surface and support in the sorption of phosphorus molecules by ferrites, ferrous hydr(oxides), and ferric hydr(oxides) ${ }^{23)}$.

\section{(5) Sampling}

The sample was taken from the effluent of the continuous system. The dissolved phosphorus and total iron concentration samples were immediately filtered using $0.20 \mu \mathrm{m}$ syringe filter.

\section{(6) Analysis}

The concentration of phosphorus and iron compounds in solution samples were measured by using a UV-Vis spectrophotometer (DR 3900, HACH Co., USA) via USEPA PhosVer 3 (Ascorbic acid method) at $880 \mathrm{~nm}$ and TPTZ (2,4,6-Tri (2-pyridinyl)-1,3,5-triazine) method at $590 \mathrm{~nm}$, respectively ${ }^{23}$. For further analysis, copper concentration was measured by Bathocuproine method at 478 $\mathrm{nm}$. The sample $\mathrm{pH}$ and oxidation and reduction potential (ORP) were measured by portable $\mathrm{pH}$ meter (D-72, HORIBA, Ltd., Japan). The dissolved oxygen (DO) concentration was measured by portable DO meter (HQ30d-flexi, HACH, USA).

\section{(7) Characterization of NZVI and $\mathrm{NZVI} / \mathrm{CuCl}_{\mathbf{2}}$}

Compositions of the iron products were analyzed by XRD (TTR, Rigaku, Tokyo, Japan). Samples were analyzed using $\mathrm{Cu}$ Ka radiation $(\lambda=1.5418 \AA)$ with a scan rate of $2^{\circ} \min ^{-1}$ and scanning range between $3^{\circ}$ and $90^{\circ}$. The surface morphologies of synthesized particles were obtained on TEM (JEM-ARM 200F, JEOL Co., Japan).

\section{(8) Calculation of overall removal efficiency}

To evaluate this system, the overall removal efficiency was calculated after determining the Removed mass of phosphorus R. $\mathbf{m}_{\mathrm{PO}^{3-}}{ }^{3-}$ (Equation (2)):

$$
\begin{aligned}
& \text { R. } \mathbf{m}_{\mathrm{PO} 4}{ }^{3-} \\
& =\left(C_{\text {inf. }} V(t)-\int_{C_{\text {eff:sand (no NZVI) }, t=0}}^{C_{\text {eff:sand (no NZVI), } t=t}} C_{t} d V(t)\right) \\
& -\int_{C_{\text {eff., } t=0}}^{C_{\text {eff., } t=t}} C_{t} d V(t)
\end{aligned}
$$

where $\mathbf{R} \cdot \mathbf{m}_{\mathrm{PO}^{3-}}{ }^{3-}$ is evaluated by subtracting phosphorus effluent mass (the integral part) from the total inlet phosphorus mass; $\mathrm{C}_{\text {inf. }} \mathrm{V}(\mathrm{t})$ as $\mathrm{C}_{\text {inf. }}$ is the concentration of phosphorus at $\mathrm{t}=0$; and $\mathrm{V}$ is the volume treated at a certain time $t$. The phosphorus mass captured by sand column (the first integral part) in the absence of NZVI was subtracted from the inlet phosphorus mass in advance. The second integral part was estimated using the trapezoidal rule starting from initial concentration to final desired concentra- 
tion that contained the target region. After that, the overall phosphorus removal efficiency was calculated by dividing the total phosphorus mass carried in the water flow ${ }^{33)}$.

\section{RESULTS}

(1) Characterization of the synthesized particles

The composition of synthesized particles was observed by analyzing the XRD pattern. Figure 2 shows the NZVI and $\mathrm{NZVI} / \mathrm{CuCl}_{2}$ bimetallic particles. Figure 2(a) shows the main peak of intensity at $44.8^{\circ}, 2 \theta$ indicating the presence of zero valent iron in the synthesized nanoscale iron materials. Figure 2(b) shows the main peaks of intensity at $44.8^{\circ}, 2 \theta$, and $65.8^{\circ}$, respectively, and the detected zero valent iron, copper, and copper iron oxide. According to this results, copper existed on the surface of NZVI as determined by the following equation 3 :

$$
\mathrm{Cu}^{2+}+2 \mathrm{e}^{-} \rightarrow \mathrm{Cu}
$$

This suggested that copper existed on the NZVI surface and could be defined as bimetallic $\mathrm{NZVI} / \mathrm{CuCl}_{2}$.

Figures 3(a) and 3(b) show the TEM images of $\mathrm{NZVI}$ and $\mathrm{NZVI} / \mathrm{CuCl}_{2}$. NZVI particles showed a chain-structure form due to the agglomeration. By contrast, bimetallic particles relatively distributed separately owing to the coating by copper. Additionally, the TEM images indicated that both synthesized particles were generally spherical and nano-scale. The estimated one particle size from the TEM images was around $100 \mathrm{~nm}$ for both samples.
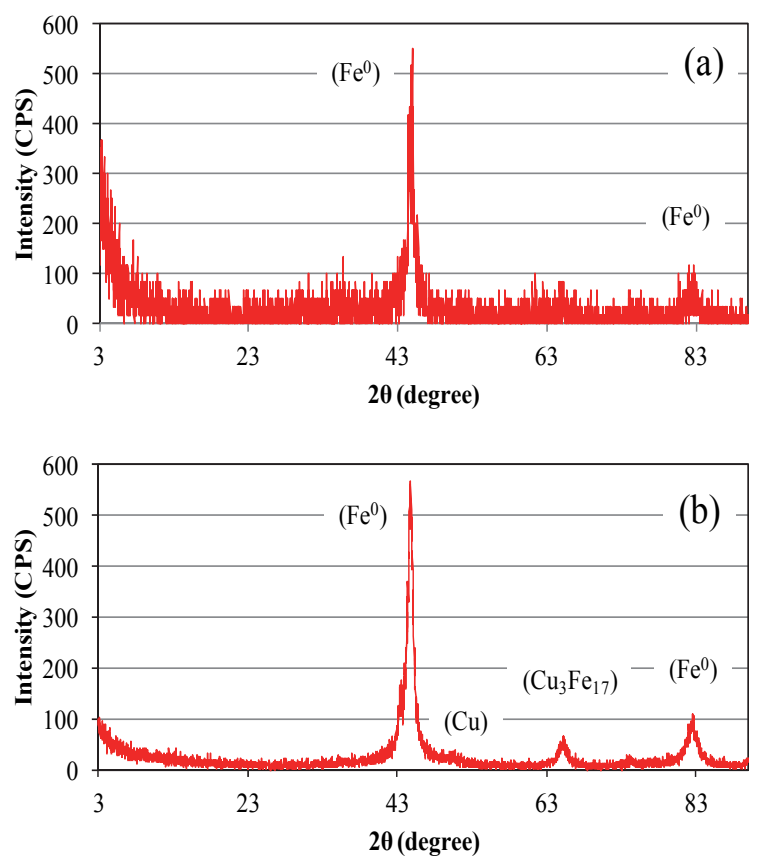

Fig. 2 The XRD pattern of NZVI (a) and $\mathrm{NZVI/CuCl} 2$ (b).
(2) The filtration effect of measuring phosphorus

The phosphorus adsorbed on the surface of NZVI must be considered to measure the phosphorus concentration accurately. Especially, the filtration before the measurement might affect the results. To check this effect, a small batch experiment was conducted and measured the phosphorus concentration after finishing the batch experiment by non-filtration and filtration. Figure 4 shows the difference in phosphorus concentrations using different sampling methods. The non-filtration and filtration phosphorus concentration were $26.70 \pm 0.32$ and $26.48 \pm 0.24 \mathrm{mg}$ $\mathrm{P} / \mathrm{L}$, respectively. According to these results, there were no significant differences between them. After this section, all phosphorus concentration were measured by filtration method.
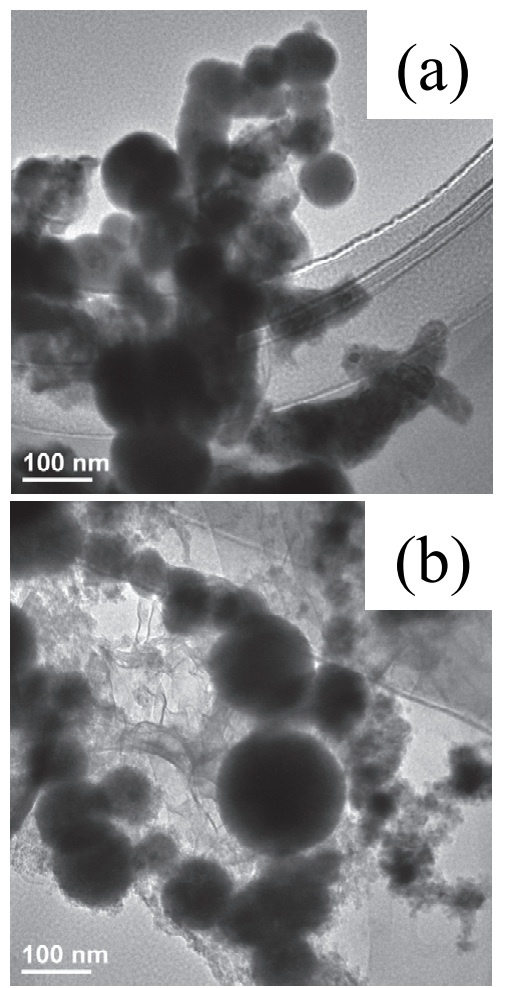

Fig. 3 The TEM images of NZVI (a) and NZVI/CuCl 2 (b).

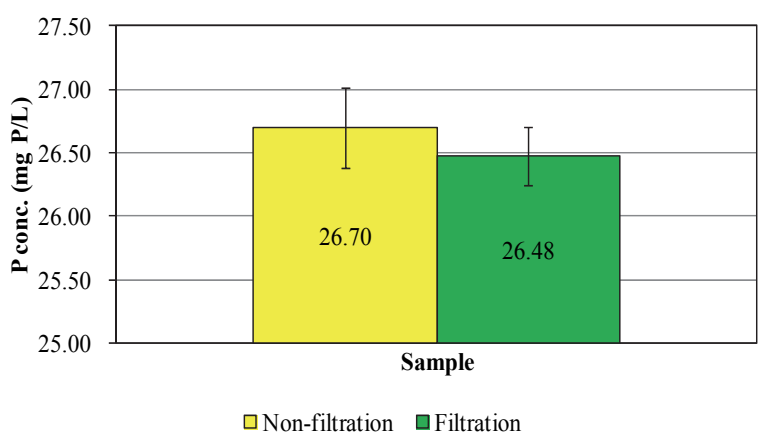

Fig. 4 The difference in phosphorus concentrations using different sampling methods (Initial P concentration: $50 \mathrm{mg}$ P/L, Solution volume: $250 \mathrm{~mL}$, Initial NZVI dosage: $250 \mathrm{mg}$, Reaction time: $3 \mathrm{~h}$, Anoxic, Temperature: $25^{\circ} \mathrm{C}$ ). 
(3) The removal performance of the continuous system

a) The phosphorus removal efficiency of each unit

Figure 5 shows the phosphorus concentration profiles obtained from each unit. Only the result of experiment 1 is shown in this section.

This result suggested that the phosphorus was removed mainly at the CSFR. Within the first three hours, high phosphorus removal efficiency was obtained from all units. After that, phosphorus concentration increased with time until the end of the experiment.

Figure 6 shows the phosphorus overall removal efficiency calculated by equation 2 . When calculating the values of the first three units, the first integral part was not considered. The phosphorus was mainly removed at CSFR and removal efficiency was achieved at $73.84 \%$.

As mentioned in Chapter 2, CSFR corresponded to the main reactor. From this calculation, the role of the CSFR was verified. At the settler and polishing unit, the phosphorus was slightly removed and the removal efficiency was achieved up to $75.20 \%$ and $77.44 \%$, respectively. With respect to the sand column, overall removal efficiency up to $81.89 \%$ was achieved, considering the first integral.

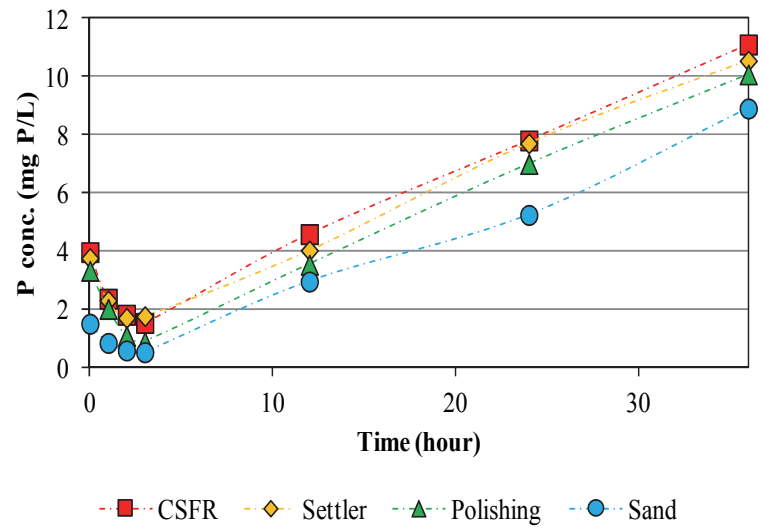

Fig. 5 The profile of phosphorus concentration.

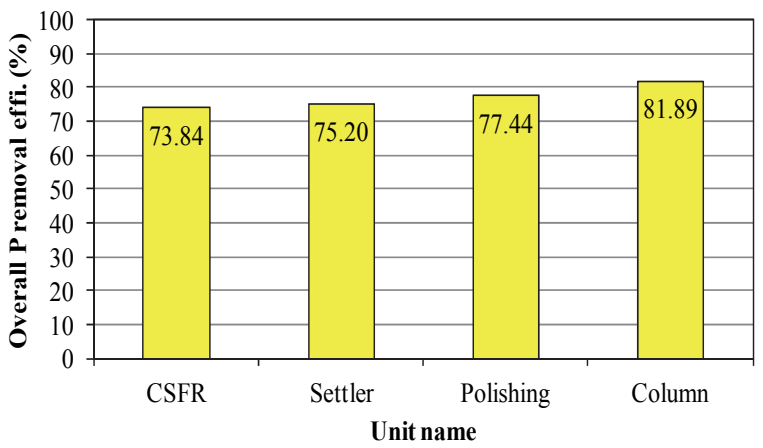

$\square$ Phosphorus overall removal efficiency

Fig. 6 The phosphorus overall removal efficiency. b) The total iron removal efficiency of each unit

Figure 7 shows the total iron concentration profiles obtained from CSFR and settler. Only the result of experiment 1 result is shown in this section. With respect to the CSFR, there were significant differences between total (non-filtration) and soluble (filtration). It is because the NZVI particles were outflowed directly to the settler. But with respect to the settler, there was no significant change between the total and soluble samples. This result suggested that almost particles were sedimented at the settler.

Figure 8 shows the total iron concentration profiles obtained from the polishing unit and sand column. There were no significant differences between total and soluble samples obtained from both units.

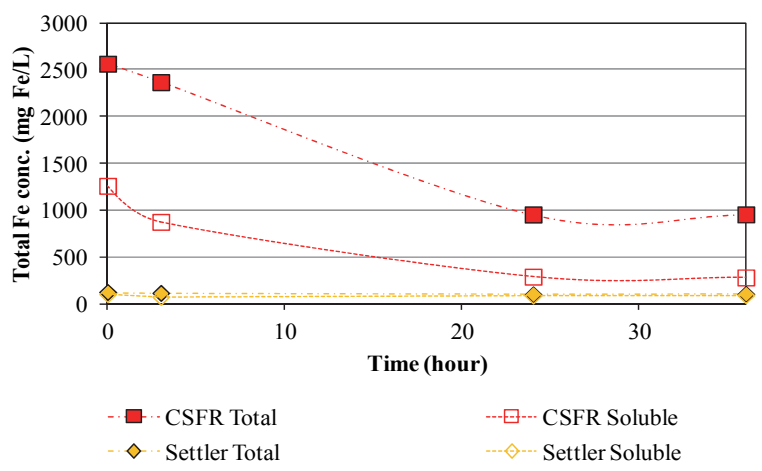

Fig. 7 The profile of total Fe concentration (CSFR and settler).

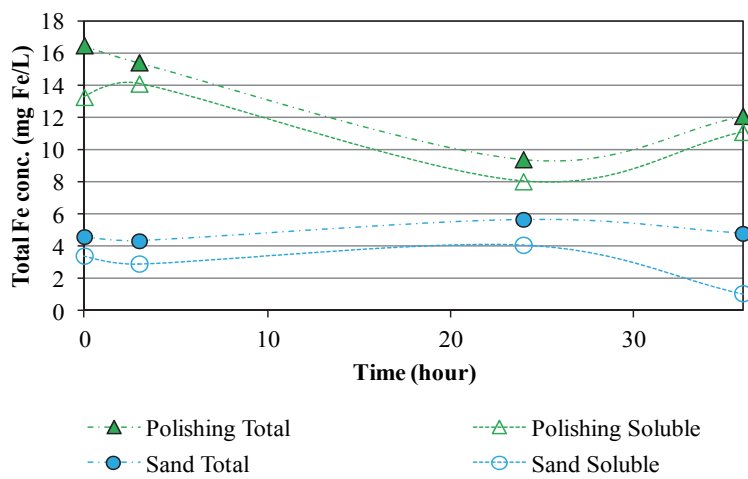

Fig. 8 The profile of total $\mathrm{Fe}$ concentration (Polishing unit and sand column).

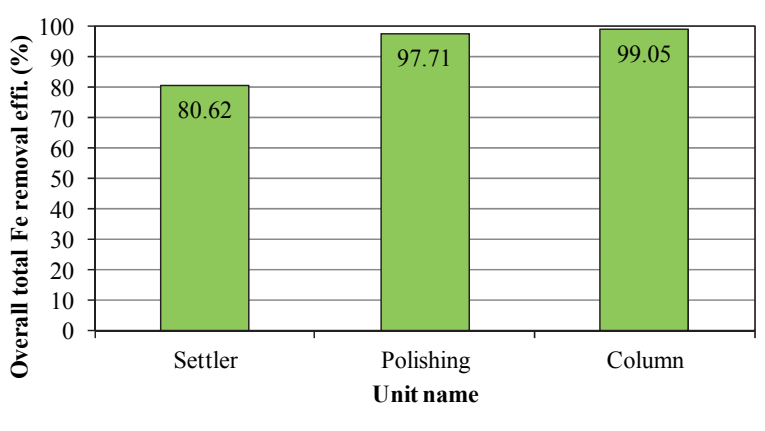

$\square$ Total Fe overall removal efficiency

Fig. 9 The total Fe overall removal efficiency. 
Figure 9 shows the total iron overall removal efficiency.

At the settler, $80.62 \%$ of total iron was sedimented and recycled to the CSFR. With respect to the polishing unit, the total iron removal efficiency of $97.71 \%$ was achieved. Finally, the highest removal efficiency of $99.05 \%$ was obtained from the sand column. These results strongly indicated that the role of each unit was achieved as mentioned in Chapter 2.

c) The relationship between phosphorus concentration and total iron concentration

Figure 10 shows the profile of the phosphorus and total iron concentration obtained from CSFR in experiment 1 . With respect to the total iron concentration, it was approximately $2,500 \mathrm{mg} \mathrm{Fe} / \mathrm{L}$ at the beginning of the experiment. However, it decreased with time to until about $1,000 \mathrm{mg} \mathrm{Fe} / \mathrm{L}$. On the other hand, phosphorus concentration increased with time.

Figure 11 shows the relationship between phosphorus concentration and total iron concentration. The correlation coefficient was $\mathrm{R}^{2}=0.7965$. The negative correlation was confirmed between these parameters. These results suggested that phosphorus concentration increased when the iron concentration decreased. These results also indicated that monitoring phosphorus concentration and total iron concentration might be useful to maintain the system.

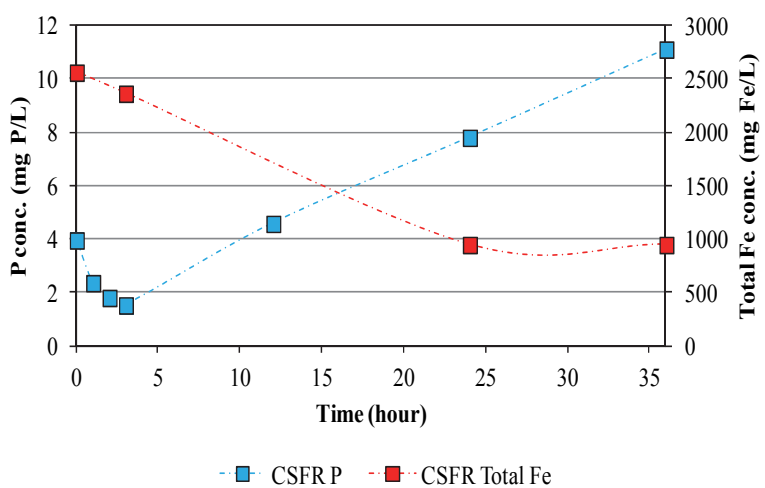

Fig. 10 The profile of the phosphorus and total Fe concentration (CSFR, experiment 1).

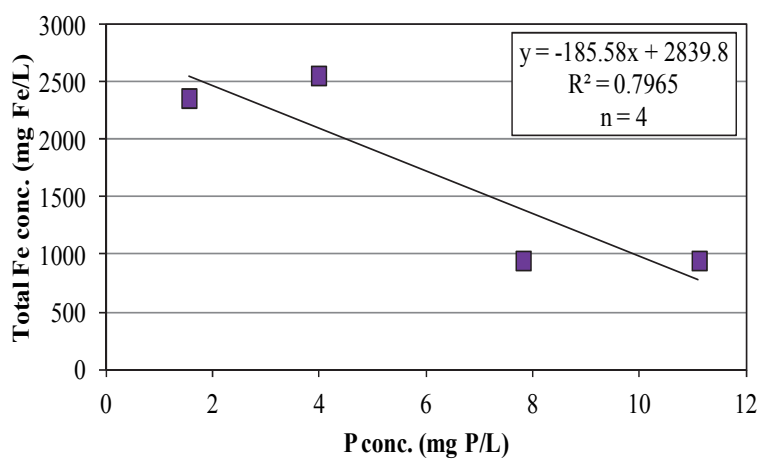

Fig. 11 The relationship between the phosphorus and total Fe concentration (CSFR, experiment 1). d) The relationship between phosphorus concentration and ORP value

Figure 12 shows the profile of the phosphorus concentration and ORP value obtained from CSFR in experiment 1 . With respect to the ORP value, it was approximately $-250 \mathrm{mV}$ at the beginning of the experiment. But it increased to a positive value with time. Similarly, the phosphorus concentration also increased with time. Figure 13 shows the relationship between phosphorus concentration and ORP value.

The correlation coefficient was $\mathrm{R}^{2}=0.7599$. The positive correlation was confirmed between these parameters in this case. These results suggested that phosphorus removal mechanisms mainly occurred when the ORP value was around $-250 \mathrm{mV}$. And when the ORP value increased, the phosphorus concentration increased simultaneously. These phenomena suggested that the ORP value would be one of the parameters to decide the new NZVI dosage timing.

e) The relationship between total iron concentration and ORP value

Figure 14 shows the profile of the total iron concentration and ORP value obtained from CSFR in experiment 1 . With respect to the ORP value, it was approximately $-250 \mathrm{mV}$ at the beginning of the experiment and the highest total iron concentration was confirmed at that time. Figure $\mathbf{1 5}$ shows the relationship between the total iron concentration and ORP value. The strong correlation coefficient of $R^{2}=$

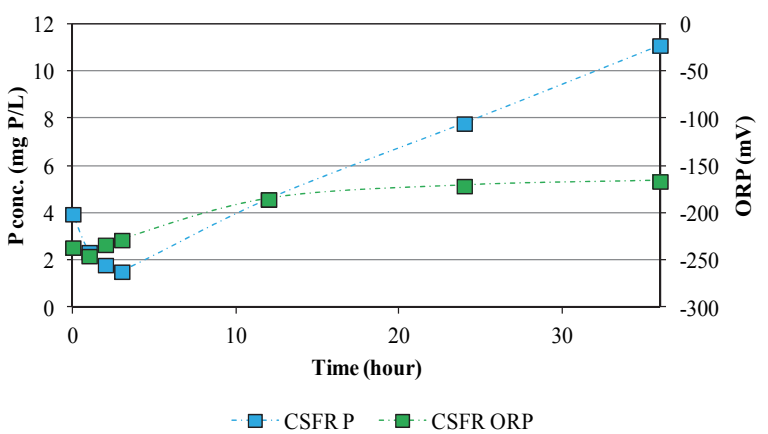

Fig. 12 The profile of the phosphorus concentration and ORP value (CSFR, experiment 1 ).

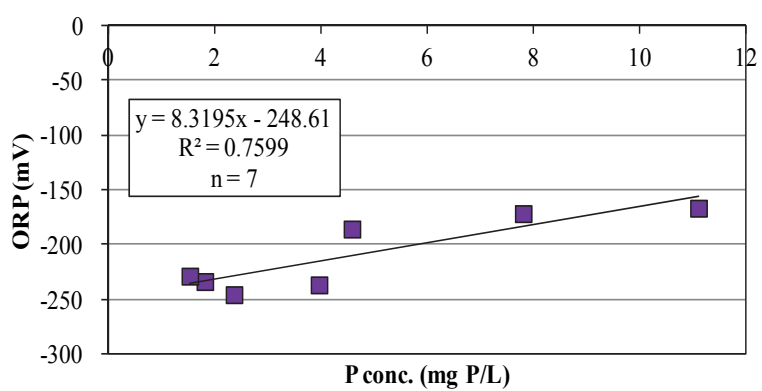

Fig. 13 The relationship between the phosphorus concentration and ORP value (CSFR, experiment 1). 


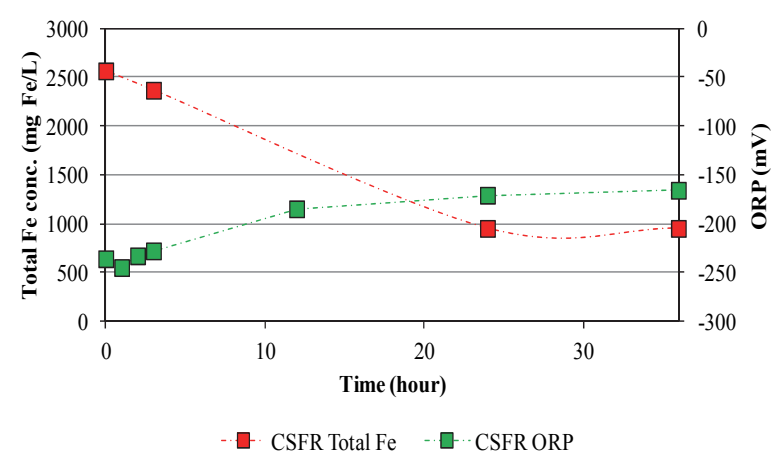

Fig. 14 The profile of the total Fe concentration and ORP value (CSFR, experiment 1).

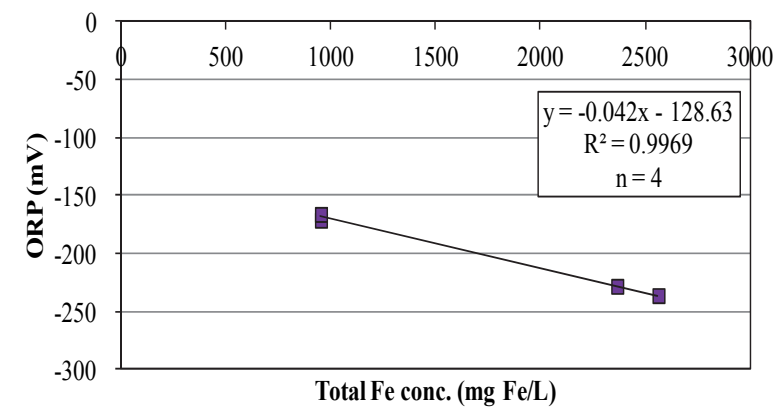

Fig. 15 The relationship between the total Fe concentration and ORP value (CSFR, experiment 1).

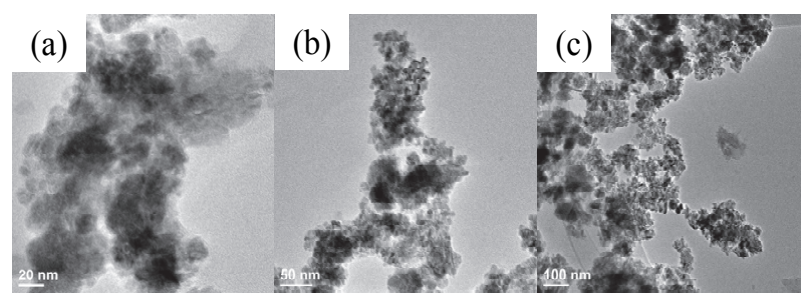

Fig. 16 The TEM images of the spent NZVI with different resolution ((a): $20 \mathrm{~nm},(\mathrm{~b}): 50 \mathrm{~nm},(\mathrm{c}): 100 \mathrm{~nm}, \mathrm{CSFR}$, experiment 1$)$

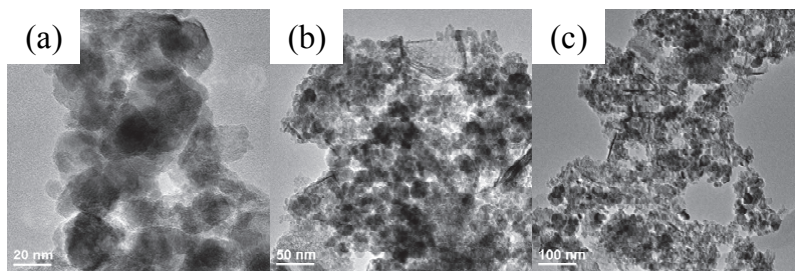

Fig. 17 The TEM images of the spent NZVI with different resolution ((a): $20 \mathrm{~nm},(\mathrm{~b}): 50 \mathrm{~nm},(\mathrm{c}): 100 \mathrm{~nm}$, Settler, experiment 1$)$.

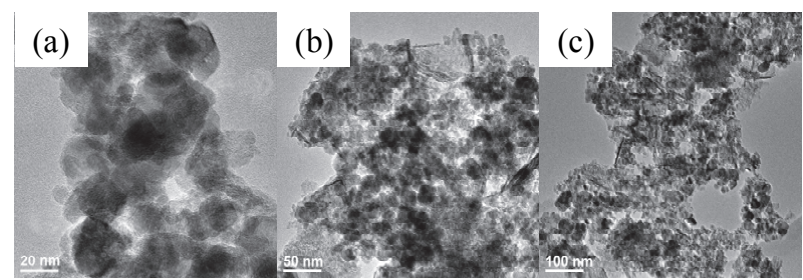

Fig. 18 The TEM images of the spent NZVI with different resolution ((a): $20 \mathrm{~nm},(\mathrm{~b}): 50 \mathrm{~nm},(\mathrm{c}): 100 \mathrm{~nm}$, Polishing unit, experiment 1$)$.
0.9969 was obtained. The negative correlationship was confirmed between these parameters in this case. These results strongly indicated that ORP value would be an important monitoring parameter in this experiment.

f) The TEM images of spent NZVI particles

Figures 16, 17, and 18 show the TEM images of spent NZVI particles obtained from CSFR, settler, and polishing unit. All particles showed complex structure compared with the fresh one. Furthermore, all particle sizes appeared larger than nanosize due to adsorption, agglomeration, and oxidation.

\section{(4) Effect of gaseous phase conditions on phos- phorus removal}

Regarding pH (Fig. 19), there was no significant difference between the three conditions in the initial three hours, and all results showed alkaline $\mathrm{pH}$ of around 8.5 to 9.9. However, after 12 hours, the $\mathrm{pH}$ of the ambient condition showed a maximum of 9.9. Also, the $\mathrm{pH}$ under aerobic condition decreased, while there was no significant change under anaerobic condition.

Regarding ORP and DO (Fig. 20), the ambient ORP value drastically decreased from $-100 \mathrm{mV}$ to $-180 \mathrm{mV}$ in the first 12 hours due to the phenomena that were explained in Chapter (3)-d. On the other hand, aerobic ORP value slightly increased.

Regarding total iron concentration (Fig. 21), all values fluctuated. It was suggested that the pathway of the water body affected the removal performance of total iron. However, all values showed less than around $4 \mathrm{mg} \mathrm{Fe} / \mathrm{L}$. From the Japanese regulation ${ }^{32)}$, the capable total soluble iron concentration discharged to the environment was below $10 \mathrm{mg} \mathrm{Fe} / \mathrm{L}$. From these results, it is suggested that the system has enough ability to remove phosphorus with less soluble iron than the Japanese standards before being discharged to the environment.

Figure 22 shows the phosphorus removal efficiency profile. In the first three hours, all conditions achieved very high removal efficiency. The ambient, aerobic, and anaerobic removal efficiency rates were $96.30 \pm 1.65 \%, 98.88 \pm 0.47 \%$, and $97.91 \pm 2.07 \%$, respectively.

\section{(5) Effect of $\mathrm{CuCl}_{2}$ on phosphorus removal}

Regarding $\mathrm{pH}$ (Fig. 23), the $\mathrm{pH}$ value of experiment 4 and experiment 5 was slightly low due to the $\mathrm{CuCl}_{2}$. In experiment 4 , the $\mathrm{pH}$ value was maintained at a constant level for the whole duration.

Regarding ORP (Fig. 24), the experiment 4 ORP value was also maintained at a constant level similar to the $\mathrm{pH}$ value result. On the other hand, the experiment 5 ORP value drastically decreased from -40 $\mathrm{mV}$ to $-120 \mathrm{mV}$ after 12 hours. 
Regarding total iron concentration (Fig. 25), experiment 4 and 5 values were less than around $1.5 \mathrm{mg}$ $\mathrm{Fe} / \mathrm{L}$.

Figure 26 shows the phosphorus removal efficiency profile. In the first three hours, all conditions achieved very high removal efficiency similar to those in experiments 1-3.

Figure 27 shows the profile of copper concentration existing in the final effluent. From the Japanese regulation $^{32)}$, the capable copper concentration discharged to the environment was below $3 \mathrm{mg} / \mathrm{L}$. This result strongly indicated that copper could be removed by the system sufficiently and it would not affect the animals in the natural water.

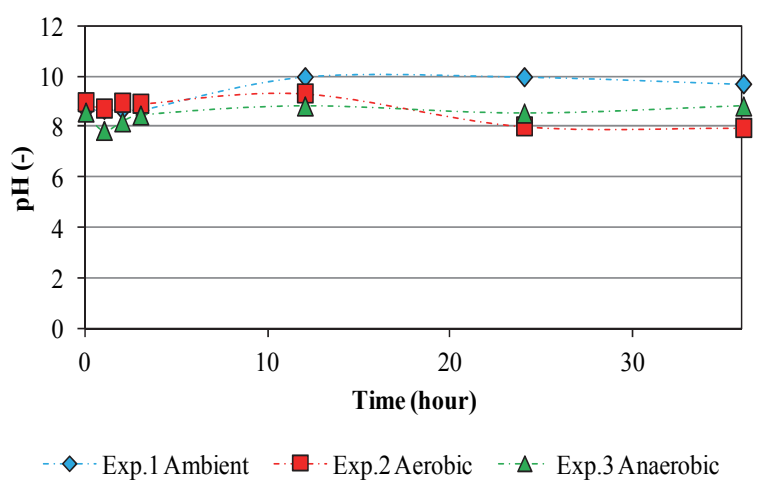

Fig. 19 The profile of the $\mathrm{pH}$ value (Measuring point: Settler).

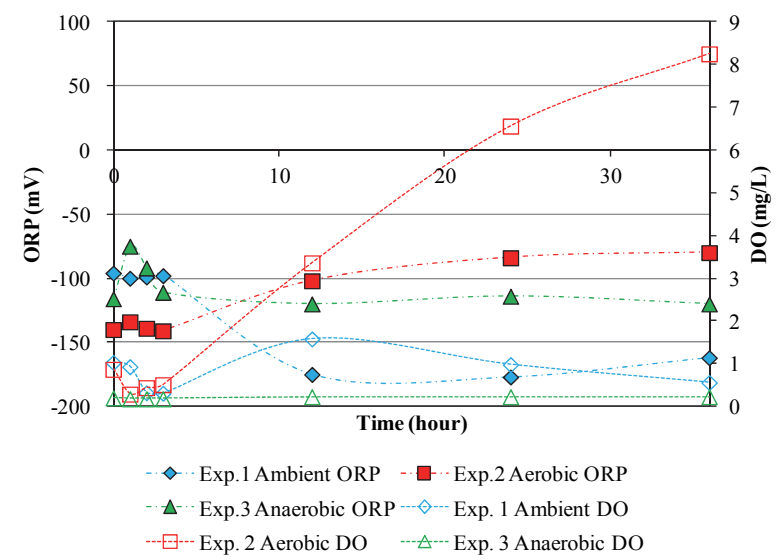

Fig. 20 The profile of ORP value and DO concentration (Measuring point: Settler).

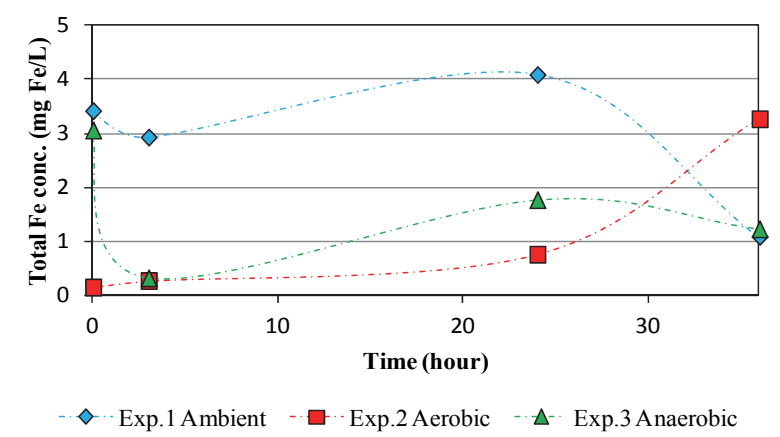

Fig. 21 The profile of the soluble total Fe conc. (Measuring point: Sand column)

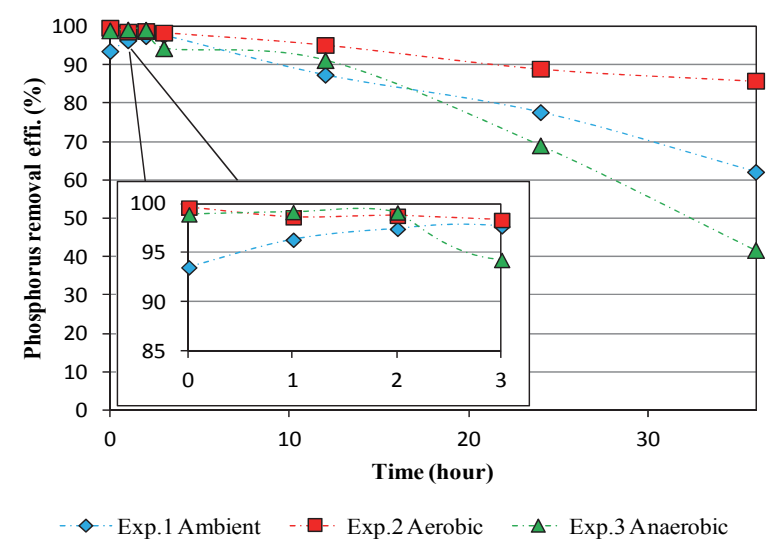

Fig. 22 The profile of the phosphorus removal efficiency (Measuring point: Sand column).

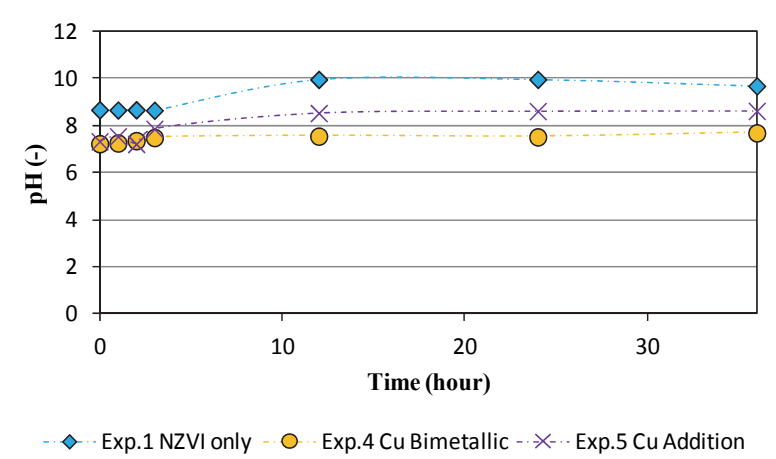

Fig. 23 The profile of the $\mathrm{pH}$ value (Measuring point: Settler).

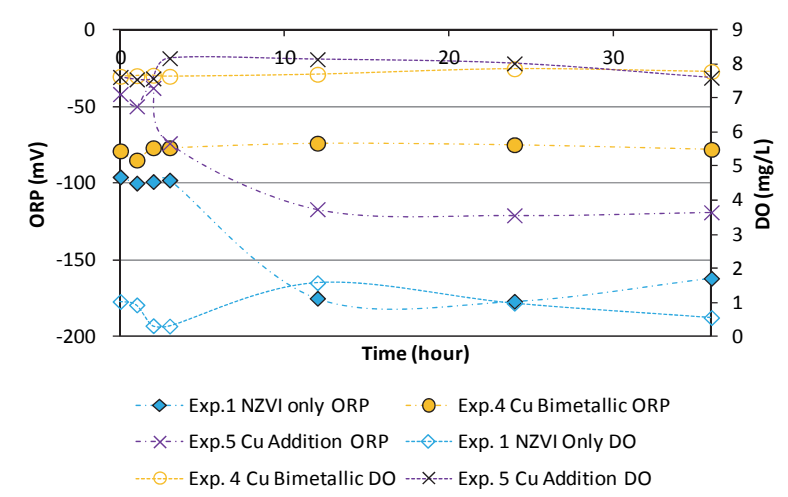

Fig. 24 The profile of ORP value and DO concentration (Measuring point: Settler).

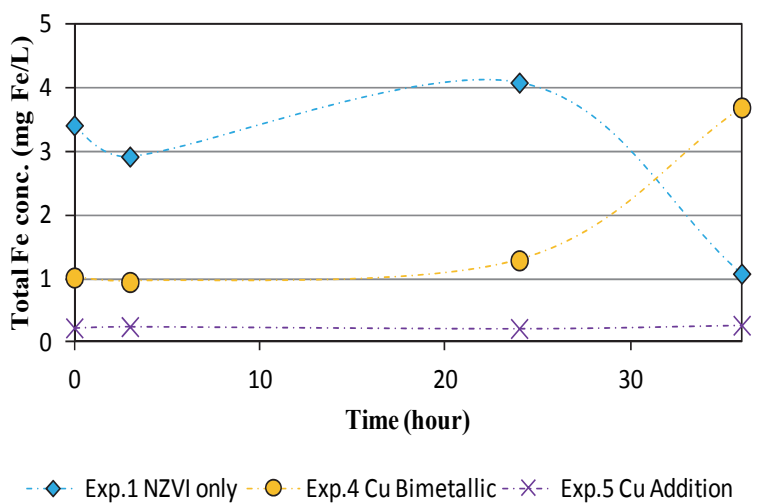

Fig. 25 The profile of the soluble total Fe conc. (Measuring point: Sand column). 


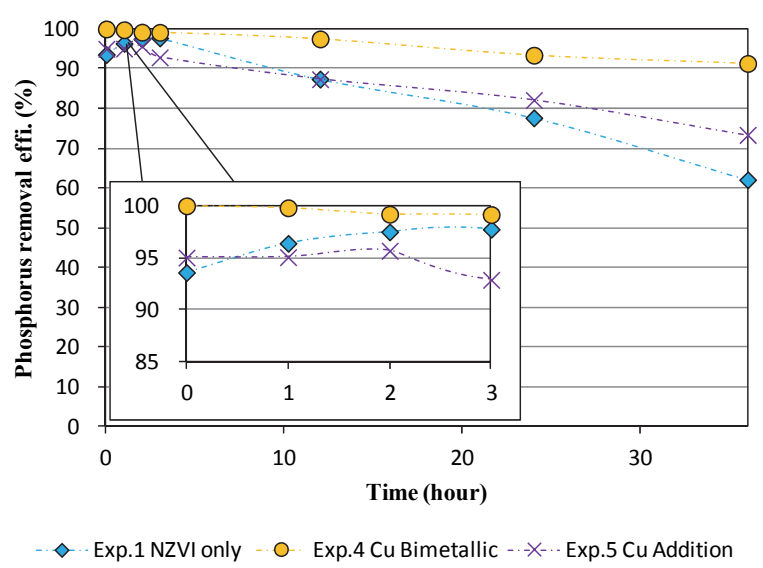

Fig. 26 The profile of the phosphorus removal efficiency (Measuring point: Sand column).

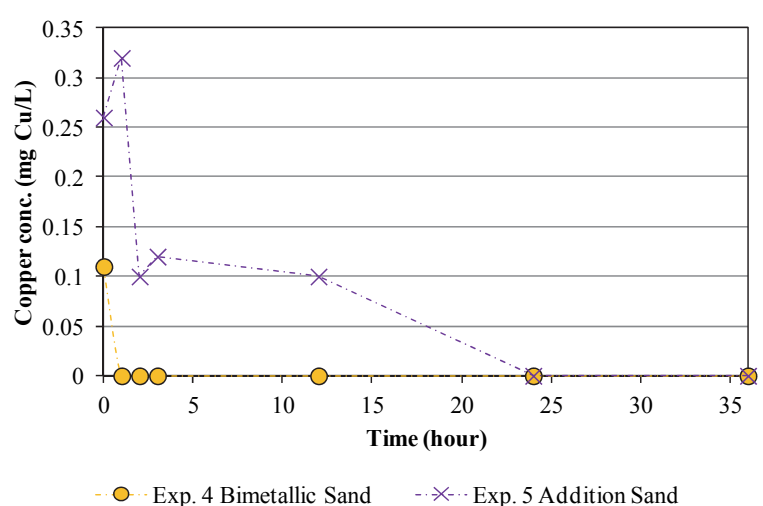

Fig. 27 The profile of the copper concentration (Measuring point: Sand column).

\section{DISCUSSION}

\section{(1) The phosphorus removal mechanisms and} overall removal efficiency

Table 2 shows the comparison of the calculated overall removal efficiency for the initial 3 hours and 36 hours. Comparing experiments 1 to 3 , the highest removal efficiency was obtained from experiment 2 (aerobic). As mentioned in the introduction part, the main mechanisms for removing phosphorus were adsorption and coprecipitation. When NZVI was added to water, NZVI corroded and $\mathrm{Fe}^{2+}$ ions eluted (Equation (4)). Particularly in the case of experiment 2 (Fig. 28), NZVI was oxidized into $\mathrm{Fe}^{2+}$ and then changed into $\mathrm{Fe}^{3+}$ (Equation (5)) in the presence of higher oxygen concentration.

Aerobic condition enhanced more iron corrosion to the nanoscale iron surface, which in turn helped in more phosphorus adsorption as ferric hydroxides (Equation (6)) and iron oxy (hydroxide) (Equation (7)) are good sorbents for contaminants ${ }^{22}$. Also, $\mathrm{Fe}^{3+}$ reacted with $\mathrm{PO}_{4}^{3-}$ directly and $\mathrm{FePO}_{4}$ (Equation (8)) was formed on the iron surface, which could obtain highly efficient removal of phosphorus due to the
Table 2 Comparison of calculated overall removal efficiency for the initial 3 hours and 36 hours.

\begin{tabular}{cccccc}
\hline Exp. No. & Exp. 1 & Exp. 2 & Exp. 3 & Exp. 4 & Exp. 5 \\
\hline $\begin{array}{c}\text { Gaseous phase } \\
\text { Ambient }\end{array}$ & Aerobic & Anaerobic & Ambient & Ambient \\
$\begin{array}{c}\mathrm{CuCl}_{2} \\
\begin{array}{c}\text { Initial 3 hours } \\
\text { removal effi. } \\
(\%)\end{array}\end{array}$ & - & - & - & Bimetal & Addition \\
$\begin{array}{c}\text { Overall } \\
\text { removal effi. } \\
(\%)\end{array}$ & 81.89 & 98.72 & 98.18 & 99.48 & 94.42 \\
\hline
\end{tabular}

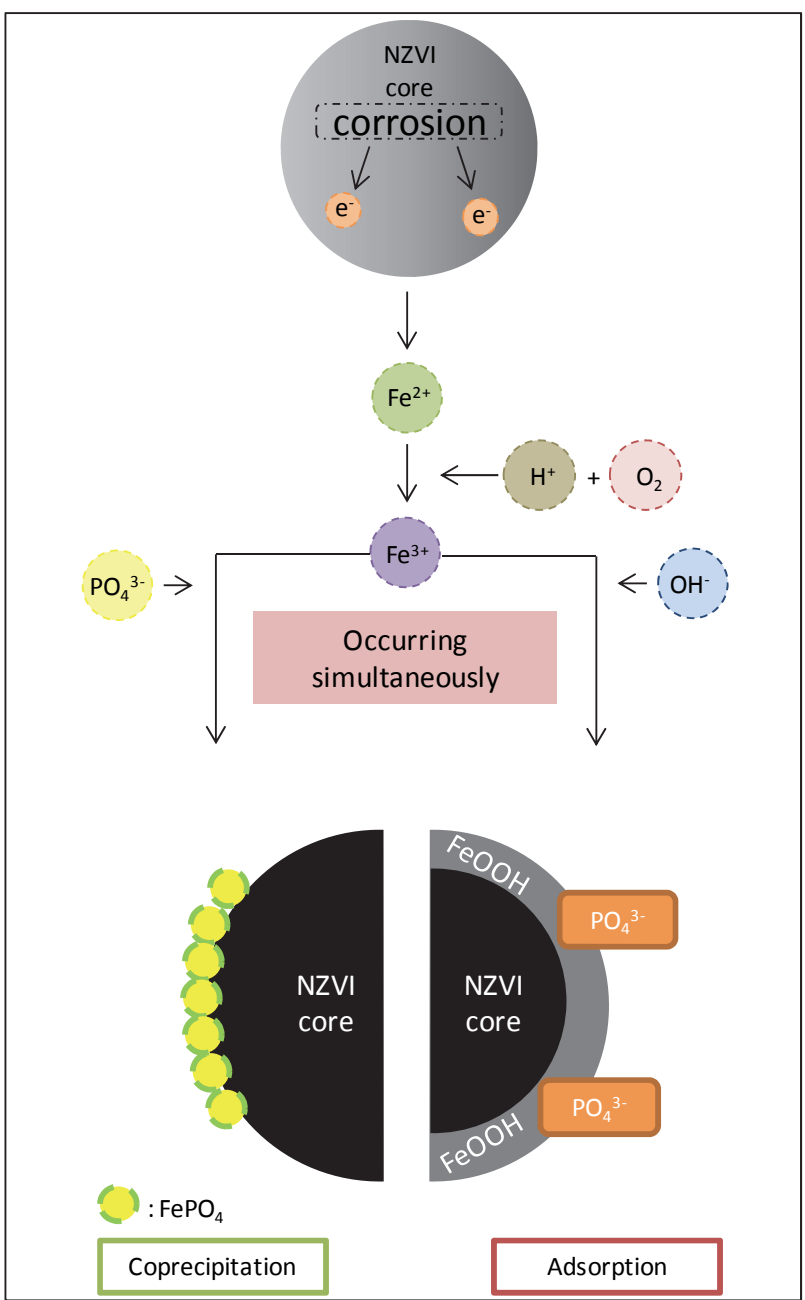

Fig. 28 Schematic image of phosphorus removal mechanisms.

relatively low Ksp constant of $1.3 \times 10^{-22} 34$ ). As a result, the highest removal efficiency was obtained from experiment 2 .

$$
\begin{array}{cc}
\mathrm{Fe}^{0}+2 \mathrm{H}_{2} \mathrm{O} \rightarrow \mathrm{Fe}^{2+}+\mathrm{H}_{2}+2 \mathrm{OH}^{-} & (4)^{35)} \\
4 \mathrm{Fe}^{2+}+4 \mathrm{H}^{+}+\mathrm{O}_{2} \rightarrow 4 \mathrm{Fe}^{3+}+4 \mathrm{H}_{2} \mathrm{O} & (5)^{35)} \\
\mathrm{Fe}^{3+}+3 \mathrm{OH}^{-} \rightarrow \mathrm{Fe}(\mathrm{OH})_{3} & (6)^{35)} \\
\mathrm{Fe}(\mathrm{OH})_{3} \rightarrow \mathrm{FeOOH}+\mathrm{H}_{2} \mathrm{O} & (7)^{18)} \\
\mathrm{Fe}^{3+}+\mathrm{PO}_{4}{ }^{3-} \rightarrow \mathrm{FePO}_{4} & (8)^{34)}
\end{array}
$$




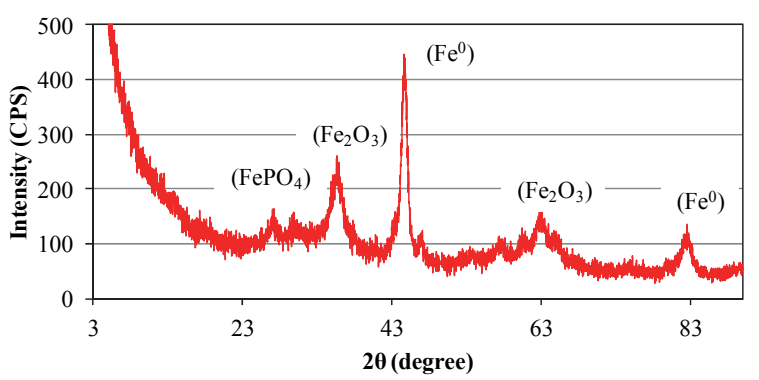

Fig. 29 The XRD pattern of spent NZVI (Experiment 1, CSFR).

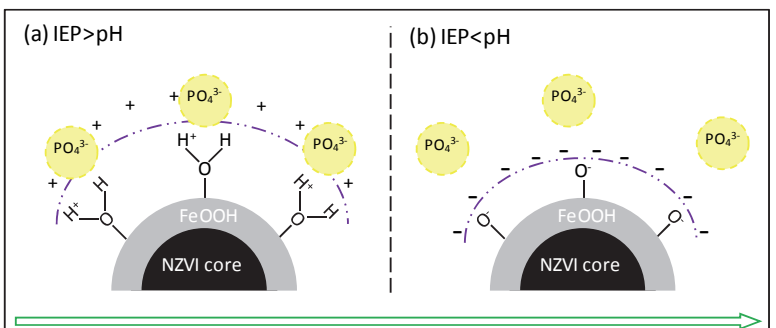

Fig. 30 The phosphorus removal mechanisms under different $\mathrm{pH}^{11), 22)}$.

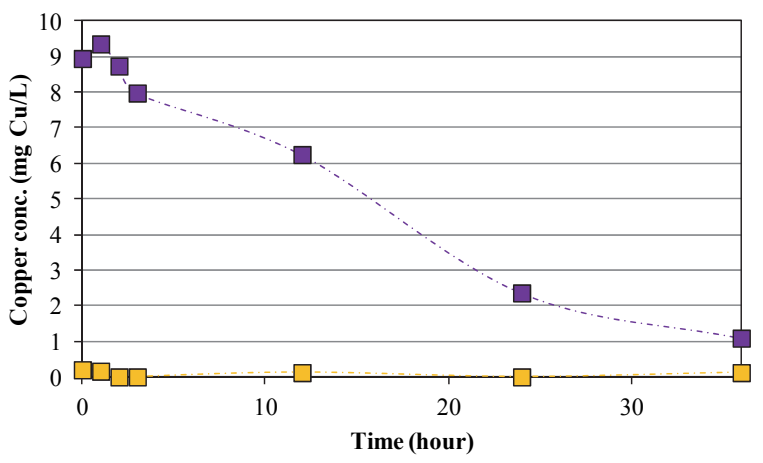

$\square$ Exp. 4 Bimetallic CSFR - $\square$ Exp. 5 Addition CSFR

Fig. 31 The profile of the copper concentration (Measuring point: CSFR).

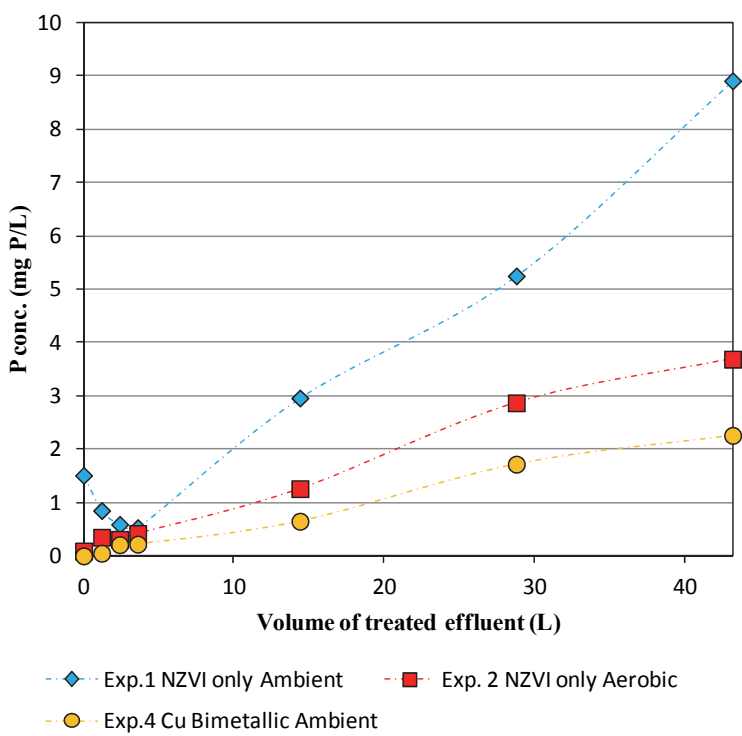

Fig. 32 The relationship between effluent volume and phosphorus concentration(Measuring point: Sand column).
Figure 29 shows the XRD pattern of spent NZVI. The $\mathrm{FePO}_{4}$ peaks appeared at $25.4^{\circ}, 2 \theta$. This result strongly indicated that coprecipitation occurred in the CSFR and it was more favorable in this system.

Comparing experiments 1,4 , and 5 , the highest overall removal efficiency was obtained from experiment $4\left(\mathrm{CuCl}_{2}\right.$ bimetallic). The bimetallic particles could provide more active site on the surface of nanoparticles and phosphorus could be adsorbed easily ${ }^{28)}$. And also some researchers have reported that acidic $\mathrm{pH}$ enhanced the phosphorus adsorption $^{11), 21)}$ (Fig. 30). It was because the isoelectric point (IEP) of $\mathrm{CuCl}_{2}$ bimetallic NZVI was $7.3^{36}$.

When the solution $\mathrm{pH}$ was lower than IEP, the particle surface became positively charged, which made the surface suitable for anion $\left(\mathrm{PO}_{4}{ }^{3-}\right)$ sorption. On the other hand, when the solution $\mathrm{pH}$ was higher than IEP, both adsorbent and adsorbate became negatively charged, leading to enhanced electric repulsion between them ${ }^{11)}$. Moreover, the phosphorus anions and $\mathrm{OH}^{-}$ions would compete to get active site, thus the adsorption efficiency would be decreased $^{37)}$. In the bimetallic case, the addition of $\mathrm{CuCl}_{2}$ increases $\mathrm{H}^{+}$ions as shown in the following reaction (Equation (9), (10)):

$$
\begin{array}{rr}
2 \mathrm{Cu}+\mathrm{H}_{2} \mathrm{O} \rightarrow \mathrm{Cu}_{2} \mathrm{O}+2 \mathrm{H}^{+}+2 \mathrm{e}^{-} & (9)^{38)} \\
\mathrm{Cu}_{2} \mathrm{O}+\mathrm{H}_{2} \mathrm{O} \rightarrow 2 \mathrm{CuO}+2 \mathrm{H}^{+}+2 \mathrm{e}^{-} \quad(10)^{38)}
\end{array}
$$

From Fig. 23, it can be seen that the $\mathrm{pH}$ values of experiments 4 and 5 were lower than those in experiment 1. Especially, the $\mathrm{pH}$ value of experiment 4 was the lowest. It suggested that discharged $\mathrm{H}^{+}$ions decreased the $\mathrm{pH}$ values of the solution and enhanced more adsorption. It was expected that bimetallic particles would increase phosphorus removal by providing active sites. However, the function as an oxidant which eluted $\mathrm{H}^{+}$was obtained at the same time.

In experiment $5, \mathrm{CuCl}_{2}$ was added to CSFR before the start of operation. Eljamal et al. ${ }^{23)}$ reported that maximum adsorption capacity by $\mathrm{NZVI} / \mathrm{CuCl}_{2}$ (addition) was enhanced with $50 \mathrm{mg} \mathrm{P} / \mathrm{g}$. However in this case, significant advantage was not confirmed by just adding $\mathrm{CuCl}_{2}$. Figure 31 shows the profile of the copper concentration existing in the effluent of CSFR. The main assumption for the addition of copper was that of enhancing iron corrosion. The results showed that higher copper outflowed from CSFR at the beginning of experiment 5 .

The result also suggested that copper outflowed before proper reaction from CSFR could start. Hence it is suggested that copper addition is not suitable for the continuous system.

From the calculated overall removal efficiency and other data, significant changes could not be obtained from experiments 2 and 4. Finally, to determine the best condition in this study, the relationship 
between phosphorus concentration and treated volume is shown in Fig. 32.

This result shows that the bimetallic condition could treat large volume phosphorus solution compared with the aerobic one and it could lead to minimization of reactors and systems, which would be a strong advantage when scaling up this system. From these results, we concluded that bimetallic condition is the best condition to remove phosphorus using this system.

\section{(2) The advantage and disadvantage of NZVI continuous system}

This section shows the advantage and disadvantage of NZVI continuous system obtained through this study.

\section{a) Advantage}

More than 99\% excellent phosphorus overall removal efficiency was obtained from aerobic and bimetallic case in the first three hours. This is the most important advantage obtained from this experiment. This result suggested that NZVI could start removing phosphorus immediately after dosing it to the water. For example, the biological technique needs time to accumulate bacteria.

\section{b) Disadvantage}

The problem with NZVI is that it does not last long. More than $95 \%$ removal efficiency could be obtained only in the initial three hours. After the removal efficiency decreases, a new NZVI dosing will be necessary.

\section{CONCLUSION}

The main purpose of this study was to develop and evaluate phosphorus removal system using NZVI particles. The continuous experiment showed that $73.84 \%$ phosphorus was removed mainly at CSFR. And $80.62 \%$ total iron was removed and recycled at the settler. On the basis of the continuous operation results, there was a strong relationship between iron concentration and ORP value $\left(\mathrm{R}^{2}=0.9969\right)$. This result indicated that ORP would be an important monitoring parameter while operating continuous systems. The aerobic condition contributed the highest phosphorus overall removal efficiency $(91.37 \%)$ due to the enhancement of iron corrosion. Also, copper bimetal particles achieved the highest removal efficiency (94.96\%) due to increase in active site and decrease in solution $\mathrm{pH}$. Finally, comparing the aerobic and bimetallic cases, we concluded that the bimetallic case was the best condition for removing phosphorus because the bimetallic condition could treat large solution volume than the aerobic one could.
ACKNOWLEDGMENT: This work was financially supported by Kyushu University, Japan.

\section{REFERENCES}

1) Mezenner, N. Y. and Bensmaili, A. : Kinetics and thermodynamic study of phosphate adsorption on iron hydroxide-eggshell waste, Chemical Engineering Journal, Vol. 147, Issues 2-3, pp. 87-96, 2009.

2) Withers, P. J. A., Elser, J. J., Hilton, J., Ohtake, H., Schippere, W. J. and van Dijkf, K. C. : Greening the global phosphorus cycle: how green chemistry can help achieve planetary P sustainability, Green Chemistry, Vol. 17, pp. 2087-2099, 2015.

3) Penn, C. J. and Warren, J. G. : Investigating phosphorus sorption onto kaolinite using isothermal titration calorimetry, Soil Science Society of America Journal, Vol. 73, No. 2, pp. 560-568, 2008.

4) Xu, H., Paerl, H. W., Qin, B., Zhu, G. and Gaoa, G. : Nitrogen and phosphorus inputs control phytoplankton growth in eutrophic Lake Taihu, China, Limnology and Oceanography, Vol. 55, Issue 1, pp. 420-432, 2010.

5) de-Bashana, L. E. and Bashan, Y. : Recent advances in removing phosphorus from wastewater and its future use as fertilizer (1997-2003), Water Research, Vol. 38, Issue 19, pp. 4222-4246, 2004.

6) Moriyama, K., Kojima, T., Minawa, Y., Matsumoto, S. and Nakamachi, K. : Development of artificial seed crystal for crystallization of calcium phosphate, Environmental Technology, Vol. 22, Issue 11, pp. 1245-1252, 2001.

7) Galarneau, E. and Gehr, R. : Phosphorus removal from wastewaters: Experimental and theoretical support for alternative mechanisms, Water Research, Vol. 31, Issue 2, pp. 328-338, 1997.

8) Baker, M. J., Blowes, D. W. and Ptacek, C. J. : Laboratory development of permeable reactive mixtures for the removal of phosphorus from onsite wastewater disposal systems, Environmental Science Technology, Vol. 32, Issue 15, pp. 2308-2316, 1998.

9) Wu, Q., Bishop, P. L., Keener, T. C., Stallard, J. and Stile, L. : Sludge digestion enhancement and nutrient removal from anaerobic supernatant by $\mathrm{Mg}(\mathrm{OH})_{2}$ application, Water Science and Technology, Vol. 44, No. 1, pp. 161-166, 2001.

10) Sakadevan, K. and Bavor, H. J. : Phosphate adsorption characteristics of soils, slags and zeolite to be used as substrates in constructed wetland systems, Water Research, Vol. 32, Issue 2, pp. 393-399, 1998.

11) Wen, Z., Zhang, Y. and Dai, C. : Removal of phosphate from aqueous solution using nanoscale zerovalent iron (nZVI), Colloids and Surfaces A: Physicochemical and Engineering Aspects, Vol. 457, pp. 433-440, 2014.

12) Barnard, J. L., Dunlap, P. and Steichen, M. : Rethinking the mechanisms of biological phosphorus removal, Water Environment Research, Vol. 89, Issue 11, pp. 2043-2054, 2017.

13) Islam, M. S., Zhang, Y., Dong, S., McPhedran, K. N., Rashed, E. M., El-Shafei, M. M., Noureldin, A. M. and El-Din, M. G. : Dynamics of microbial community structure and nutrient removal from an innovative side-stream enhanced biological phosphorus removal process, Journal of Environmental Management, Vol. 198, Part 1, pp. 300-307, 2017.

14) Wang, C., Luo, H., Zhang, Z., Wu, Y., Zhang, J. and Chen, S. : Removal of $\mathrm{As}(\mathrm{III})$ and $\mathrm{As}(\mathrm{V})$ from aqueous solutions using nanoscale zero valent iron-reduced graphite oxide modified composites, Journal of Hazardous Materials, Vol. 268, pp. 124-131, 2014.

15) Gueye, M. T., Petrucci, E. and Di Palma, L. G. : Chemical 
reduction of hexavalent chromium (VI) in soil slurry by nano zero valent iron, Chemical Engineering Transaction, Vol. 43, pp. 655-660, 2015.

16) Soto, K. T. H., Ortiz-Quiles, E. O., Betancourt, L. E., Larios, E., José-Yacaman, M. and Cabrera, C. R. : Photoelectrochemical solar cells prepared from nanoscale zerovalent iron used for aqueous $\mathrm{Cd}^{2+}$ removal, ACS Sustainable Chemistry \& Engineering, Vol. 4, No. 3, pp. 738-745, 2016.

17) Xiu, R., He, S. and Song, H. : Removal of nitrate nitrogen by nanoscale zero-valent iron supported on modified diatomite, CIESC Journal, Vol. 67, No. 9, pp. 3888-3894, 2016.

18) Kim, D. G., Hwang, Y. H., Shin, H. S. and Ko, S. O. : Kinetics of nitrate adsorption and reduction by nano-scale zero valent iron (NZVI): Effect of ionic strength and initial $\mathrm{pH}$, KSCE Journal of Civil Engineering, Vol. 20, Issue 1, pp. 175-187, 2016.

19) Barreto-Rodrigues, M., Silveira, J., Zazo, J. A. and Rodriguez, J. J. : Synthesis, characterization and application of nanoscale zero-valent iron in the degradation of the azo dye Disperse Red 1, Journal of Environmental Chemical Engineering, Vol. 5, Issue 1, pp. 628-634, 2017.

20) Nurmi, J. T., Tratnyek, P. G., Sarathy, V., Baer, D. R., Amonette, J. E., Pecher, K., Wang, C., Linehan, J. C., Matson, D. W., Penn, R. L. and Driessen, M. D. : Characterization and properties of metallic iron nanoparticles: Spectroscopy, electrochemistry, and kinetics, Environmental Science\& Technology, Vol. 39, Issue 5, pp. 1221-1230, 2005.

21) Xie, B., Zuo, J., Gan, L., Liu, F. and Wang, K. : Cation exchange resin supported nanoscale zero-valent iron for removal of phosphorus in rainwater runoff, Front. Environ. Sci. Eng., Vol. 8, Issue 3, pp. 463-470, 2014.

22) Almeelbi, T. and Bezbaruah, A. : Aqueous phosphate removal using nanoscale zero-valent iron, Journal of Nanoparticle Research, Vol. 14, 900, 2012.

23) Eljamal, O., Khalil, A. M. E., Sugihara, Y. and Matsunaga, N. : Phosphorus removal from aqueous solution by nanoscale zero valent iron in the presence of copper chloride, Chemical Engineering Journal, Vol. 293, pp. 225-231, 2016.

24) Zhang, Q., Liu, H., Chen, T., Chen, D., Li, M. and Chen, C. : The synthesis of NZVI and its application to the removal of phosphate from aqueous solutions, Water Air Soil Pollut., Vol. 228, 321, 2017.

25) Wang, S., Gao, B., Li, Y., Creamer, A. E. and He, F. : Adsorptive removal of arsenate from aqueous solutions by biochar supported zero-valent iron nanocomposite: Batch and continuous flow tests, Journal of Hazardous Materials, Vol. 322, pp. 172-181, 2017.

26) Li, S., Wang, W., Liang, F. and Zhang, W.-X.: Heavy metal removal using nanoscale zero-valent iron (nZVI): Theory and application, Journal of Hazardous Materials, Vol. 322, pp. 163-171, 2017.

27) Hwang, Y.-H., Kim, D.-G. and Shin, H.-S. : Effects of synthesis conditions on the characteristics and reactivity of nano scale zero valent iron, Applied Catalysis B: Environmental, Vol. 105, pp. 144-150, 2011.

28) Amen, T. W. M., Eljamal, O., Khalil, A. M. E. and Matsunaga, N. : Wastewater degradation by iron/copper nanoparticles and the microorganism growth rate, Journal of Environmental Sciences (China), Article in Press, 2018.

29) Maamoun, I., Eljamal, O., Khalil, A. M. E., Sugihara, Y. and Matsunaga, N. : Phosphate removal through nano-zero-valent iron permeable reactive barrier; column experiment and reactive solute transport modeling, Transport in Porous Media, Vol. 125, Issue 2, pp 395-412, 2018.

30) Shubair, T., Eljamal, O., Khalil, A. M. E., Tahara, A. and Matsunaga, N. : Novel application of nanoscale zero valent iron and bimetallic nano-Fe/Cu particles for the treatment of cesium contaminated water, Journal of Environmental Chemical Engineering, Vol. 6, Issue 4, pp. 4253-4264, 2018.

31) Hosseini, S. M., Ataie-Ashtiani, B. and Kholghi, M. : Nitrate reduction by nano-Fe/Cu particles in packed column, Desalination, Vol. 276, Issues 1-3, pp. 214-221, 2011.

32) National Minimum Effluent Standards, Ministry of the Environment, Japan.

33) Khalil, A. M. E., Eljamal, O., Saha, B. B. and Matsunaga, N. : Performance of nanoscale zero-valent iron in nitrate reduction from water using a laboratory-scale continuous-flow system, Chemosphere, Vol. 197, pp. 502-512, 2018.

34) Liu, H., Chen, T., Zou, X., Xie, Q., Qing, C., Chen, D. and Frost, R. L. : Removal of phosphorus using NZVI derived from reducing natural goethite, Chemical Engineering Journal, Vol. 234, pp. 80-87, 2013.

35) Semerád, J. and Cajthaml, T.: Ecotoxicity and environmental safety related to nano-scale zerovalent iron remediation applications, Applied Microbiology and Biotechnology, Vol. 100, Issue 23, pp. 9809-9819, 2016.

36) Tu, Y.-J. and You, C.-F. : Phosphorus adsorption onto green synthesized nano-bimetal ferrites: Equilibrium, kinetic and thermodynamic investigation, Chemical Engineering Journal, Vol. 251, pp. 285-292, 2014.

37) Anirudhan, T. S., Noeline, B. F. and Manohar, D. M. : Phosphate removal from wastewaters using a weak anion exchanger prepared from a lignocellulosic residue, Environmental Science \& Technology, Vol. 40, Issue 8, pp. 2740-2745, 2006.

38) Khalil, A. M. E., Eljamal, O., Jribi, S. and Matsunaga, N. : Promoting nitrate reduction kinetics by nanoscale zero valent iron in water via copper salt addition, Chemical Engineering Journal, Vol. 287, pp. 367-380, 2016.

(Received March 23, 2018) 